Article

\title{
Overview of the Croatian Land Administration System and the Possibilities for Its Upgrade to 3D by Existing Data
}

\author{
Nikola Vučić ${ }^{1, *}$, Miodrag Roić $^{2}$ (D), Mario Mađer ${ }^{2}$ (D), Saša Vranić ${ }^{2}$ (D) and \\ Peter van Oosterom ${ }^{3}$ \\ 1 State Geodetic Administration, Gruška 20, 10000 Zagreb, Croatia \\ 2 Faculty of Geodesy, University of Zagreb, Kačićeva 26, 10000 Zagreb, Croatia; mroic@geof.hr (M.R.); \\ mmadjer@gmail.com (M.M.); svranic@geof.hr (S.V.) \\ 3 Faculty of Architecture and the Built Environment, Department OTB, GIS Technology Section, \\ Delft University of Technology, P.O. Box 5030, 2600 GA Delft, The Netherlands; \\ p.j.m.vanOosterom@tudelft.nl \\ * Correspondence: nikola.vucic@dgu.hr; Tel.: +385-1-6165-439
}

Received: 31 March 2017; Accepted: 17 July 2017; Published: 20 July 2017

\begin{abstract}
This paper explores the laws and other legal acts related to the Croatian 3D cadastre with an emphasis on those which relate to interests in strata, spatial planning, and other regulations that are valid or were valid on Croatian territory. The effects of the application of these regulations on the present situation of registration in cadastre and land register were considered. This paper also explores current legal, institutional, and technical solutions implemented in the Croatian Land Administration System and the possibilities for its upgrade to 3D cadastre. Implementation of any technological option to establish a 3D cadastre is tightly related to legislation. Hence, legislation and technological options are considered to find solutions that will be possible to implement. One suggestion presented in this paper was to use other sources of 3D data such as topographic signs or symbols used to represent topographic objects on 2D maps. In combination with other geodetic and cartographic products, useful information can be obtained, often quite relevant to provide a reference context for a 3D cadastre. Topographic signs on topographic maps and on other geodetic products provide a representation of complex real-world situations (tunnels, bridges, overpasses etc.) that are not usually presented on cadastral maps. This paper presents the possibility of utilizing those topographic signs to achieve the first steps towards establishing a 3D cadastre. Furthermore, this study proposes the establishment of a 3D Multipurpose Land Administration System as the most efficient system of land administration in a time when spatial information is easier to obtain than ever before and traditional real estate registers are subject to frequent and demanding changes.
\end{abstract}

Keywords: 3D cadastre; 3D real property; land administration; legal; institutional; technical; topographic signs

\section{Introduction}

A cadastre is generally a parcel-based, up-to-date land information system containing records of real properties and interests (i.e., rights, restrictions and responsibilities). A more extensive use of land administration information began with the development of multipurpose cadastres. Their establishment has proven to be quite demanding, and it is difficult to find efficient multipurpose cadastres in any country. It was only the development of information technologies that really opened up the possibilities for the development of Multipurpose Land Administration Systems (MLAS), as currently, the differences between the systems for registering land and the systems for registering land tenure do not allow a unified approach between countries [1]. 
The amount and the complexity of the information maintained as per the public authority regulations are constantly increasing, and are strongly related to the development of technology. The possibilities of new technologies are also constantly increasing, thus opening the possibility of collecting new, additional information not previously acquired due to technical difficulties. Cadastral data are basic data for land administration systems. Their availability in a digital form makes them interesting for the increasing number of new areas of human activity and is essential for their further development, which has led to a constant increase in demand for cadastral information. Therefore, countries have to work on improving the information flow by collecting and maintaining 3D cadastral data to keep up with the growing requirements, especially those related to efficient land administration.

The definitions and descriptions of 3D properties often focus on the technical and registration aspects rather than the legal aspects. In the legal category, most studies have addressed national legislation and its practical use. For more than 10 years, Paulsson and Paasch [2] conducted a thorough analysis of the overall field of 3D cadastres and concluded that further fundamental legal research on 3D property was required. The same assumption was also valid for the Croatian case and was confirmed by insight into the general state of registered land administration data.

During the Second International 3D Cadastres Workshop in Delft, The Netherlands (2011), five practical issues were highlighted [3]. By applying and answering these questions, a close impression of the general state of 3D data in the Republic of Croatia was obtained:

- Which types of 3D cadastral objects (3D properties) can be registered? Are these always related to constructions (buildings, pipelines, tunnels, etc.) as in Norway and Sweden, or could they be any part of the 3D space (both airspace or in the subsurface)?

- In cases where infrastructure objects cross 2D parcel boundaries (such as long tunnels, pipelines, and cables networks), should these be divided based on the surface parcels (as in Queensland, Australia), or treated as one cadastral object (as in Sweden and the Netherlands)?

- How do we deal with the fact that the legal status of such objects does not have to be the same for all ground parcels? For example, one construction located on three ground parcels, each on the basis of another type of right (e.g., easement, restrictive covenant, lease).

- For the representation (and initial registration) of a 3D cadastral object, is the legal space specified by its own coordinates in a shared reference system (as is the practice for 2D in most countries), or is it specified with reference to existing topographic objects/boundaries?

- Should 3D registration and visualization reflect the actual dimensions, or is it sufficient to have a visualization of property units in buildings based on standard floor-to-floor heights, as in Spain? What is the legal value of these boundaries? Is an investigation of the source documents (title deed, survey plan) needed to obtain legally binding information?

In this paper, amongst other things, the answers to these questions are given and elaborated from a Croatian perspective. These findings serve as a starting point and general overview of the Croatian Land Administration System. We believe that most data for establishing the 3D cadastre in the Republic of Croatia has already been collected and maintained, but often in a form not suitable for direct implementation. Therefore, the aim of this paper is to show the possibilities of implementing a $3 \mathrm{D}$ cadastre by using the data already registered in the existing official registers and databases that are part of the Croatian Land Administration System. The objectives undertaken to achieve this aim can be summarized in several steps, which include an overview of the relevant Croatian legislation, an analysis of the existing data in official registers, and a proposal of the methods for establishing the 3D cadastre by using this data.

The rest of the paper is organized as follows. Section 2 deals with the legal and technical aspects of a Croatian 3D cadastre, while Section 3 describes its institutional aspects. Section 4 lists available sets of data which could be used in establishing a 3D MLAS. A subsection on technical aspects investigates how 3D models can be created from the listed data, but without going into a deeper analysis of these procedures. Section 5 deals with 3D topographical signs, while Section 6 describes the link 
between topographical signs, cadastral maps, and cadastral registry entries. The paper ends with our conclusions.

\section{Legal and Technical Aspects of the Croatian 3D Cadastre}

Business and technological systems of public administration are largely based on registers. The terms registry or register are used to denote the organization where information on registered land rights are held. Information on registered land is typically textual and spatial, with the former typically maintained in a registry (or a land register in Croatia) and the latter in a cadastre office. Introducing interoperability into the registers is one of the key drivers for optimizing public administration, starting from the simple automation of existing processes, to the overall transformation of the system, and the construction of modern user-oriented services. An additional incentive for such a transformation was the foreseeable need for interoperability between the national system of registers and the European Union (EU) registers, and potentially in the future with other registers worldwide. The current system of registers in the Republic of Croatia is significantly vertically structured [4].

Spatial data and data on real property in Croatia are managed in multiple registers with many end users. Basic registers include the Cadastre and Land register. The Cadastre register maintains data on the position, shape, and area of real properties, while the Land register registers data on rights, restrictions, and responsibilities. Responsible institutions of public authority are the State Geodetic Administration (for the Cadastre register) and municipal courts (for the Land register). In cadastral offices (20 regional cadastral offices with their 92 branches as well as the Municipal Office for Cadastre and Geodetic Works of the City of Zagreb), real properties are registered based on their technical characteristics. The cadastral data on real properties (cadastral parcels) are the basis for the establishment, renewal, storage, and maintenance of land registers that are kept across 109 land register offices. In land registers, the data on cadastral parcel title holders are associated with the data on cadastral parcels defined by the cadastre. Real property in Croatian real property law is based on the superficies solo cedit principle, where a land surface parcel includes everything relatively permanently associated with the parcel on or below the land surface (primarily buildings, houses, etc.). A real property (LA_BAUnit in ISO 19152), in Croatian legislation, may consist of one or more land parcels registered in the land register in the same property sheet, hence they are legally combined in a single body (registered land unit). Grass, trees, fruits, and all valuable commodities provided on the surface of the land are parts of this real property until the land is divided.

The Croatian Land Administration System (LAS) is in the process of registering 3D cadastral objects related to construction (buildings, pipelines, tunnels). In cases where infrastructure objects cross 2D parcel boundaries such as long tunnels, pipelines, and cable networks, the Croatian LAS treats them as one cadastral object. The building and physical planning laws are very strict and do not allow for differences in legal status between the ground parcels where such an object has been built, e.g., one construction situated on three ground parcels, each on the basis of another type of right (e.g., easement, restrictive covenant, lease). For building a new construction in a similar situation, the right of construction can be utilized. The right of construction is a limited real right on someone's parcel, and it entitles the construction right holder to build a construction on the surface of other owner's land or underneath it; and the owner of the land has to agree to this construction. The right of construction in legal terms is equal to the definition of real property. For the representation (and initial registration) of a 3D cadastral object, its legal space is specified by reference to existing topographic objects/boundaries. For the first implementation of the Croatian 3D cadastre and visualization of property units in buildings, it was sufficient to use standard floor-to-floor heights.

\subsection{Buildings and Particular Parts of a Real Property}

Buildings are registered in the cadastre at the obligatory request of a party. A geodetic report prepared by the authorized surveying company must be supplied with this request. The responsible cadastral office must first review and certify the report. Since 2007, cadastral offices have partially 
participated in controlling the legalities of the construction of all buildings. As a precondition for registering buildings into the cadastre, and then taking that data into land registers, the geodetic reports must also include the building permit or other relevant documents. Any particular parts of real properties can also be registered in the non-technical (written) part of the cadastral documentation. However, given that all the necessary data cannot be recorded in as much detail as in the Land register, there can be inconsistencies between the cadastral and land register data when describing particular parts of the same real property.

Buildings and other structures are registered in the cadastre with the following attributes: location (2D coordinates), area, intended building use, building name, and house number. A land register takes over two-dimensional data on real property from the cadastre. Real property may be further divided into common and particular parts, and registered in the land register based on the report on the particular part of the real property (Figure 1). In this way, co-owners of a real property have a co-owner relationship on the common parts, and each of them becomes an individual owner of a particular part (for example an apartment or office space). This way of registering particular parts began in 1996, and has yet to be implemented for the majority of real properties, as land register registration is purely voluntary.

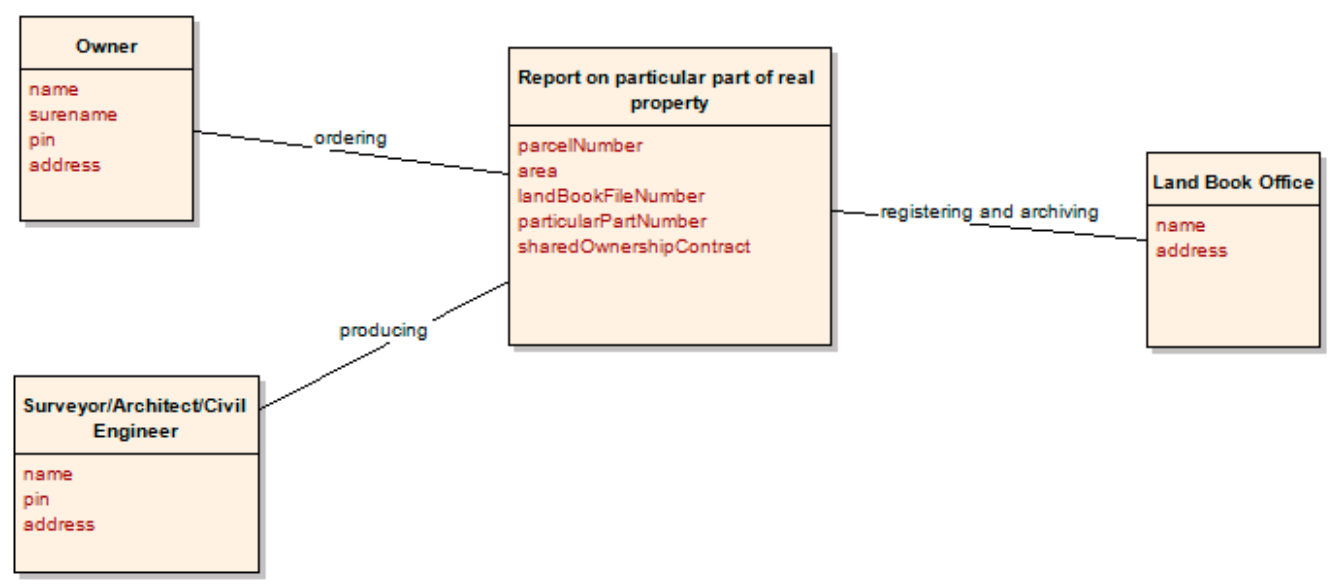

Figure 1. Schematic presentation of creating a report on a particular part of a real property.

Data on buildings are transcribed into land registers based on the data delivered to the land register by the cadastral office. Ownership of a particular part of property (e.g., an apartment or office space) is realized through registration in a land register. These particular parts may be registered if they make independent units of use. Particular parts may include balconies, terraces, basements, and attics, under the strict condition that they exclusively serve a single particular part and that they are clearly separated from other real property parts. The registration of particular parts of a real property in the land register is not possible without a report on the particular part, which in legal terms means the retention of a real property as a single body. This same procedure is commonly used in land registers to formally unify the land (which was often publicly owned) with the building constructed on that land. Partition of the real property establishes ownership of a particular part of a real property (apartment, office space, garage, etc.) that becomes associated with a proportionally shared part on the property. A fair relationship in financing the maintenance of a building is furthermore made possible by establishing the ratio of each party's ownership in the common real property and hence each party's proportional share in the shared ownership of common parts.

The report on a particular part of a real property establishes the size and shape of the common and particular parts of a single real property (apartment, office space, etc.), and draws connections for reference purposes against the real property as a unit. Additionally, data on particular parts must be technically processed with drawings of particular and common parts with the required labels and 
areas of particular parts. Figure 2 shows two particular parts of a real property differentiated by hatch style. Drawings like these are provided in analogue format. Furthermore, a shared ownership contract must also be provided.

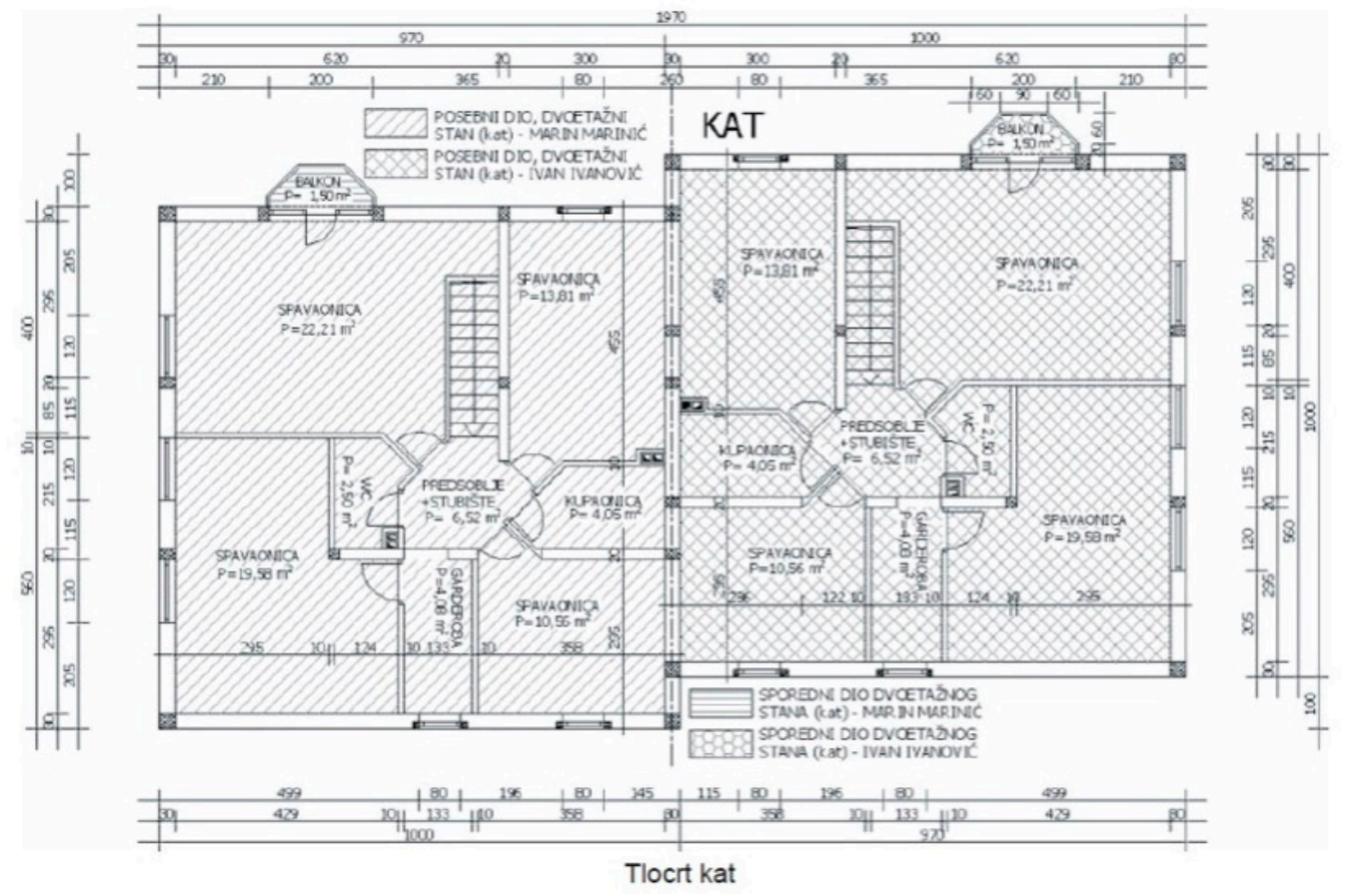

Figure 2. Particular parts of a real property [5].

According to the Regulation of the Connecting Land Register and the Book of Deposited Contracts [6], the legal obligation of the building manager is to start the procedure of connecting the land register with the Book of Deposited Contracts. This regulation was brought about as it was noticed that many buildings built several decades ago were not registered in the cadastre or the land register, and have not been partitioned. According to the mentioned regulation, the description of the particular part of a real property contains the data on intended use (office space, apartment, or other), number of rooms, position of particular part in a building, and the surface of the particular part (for example, a two-bedroom apartment on the first floor, right side, with the usable area of $52 \mathrm{~m}^{2}$ ). Furthermore, the description of a particular part of a real property also mentions the additions (for example, a woodshed, a garage, a parking space, a balcony, a garden, a terrace, and similar), along with their area, if there is such data.

It is necessary to standardize the appearance and methods of creating building subdivision plans. A building information modelling (BIM)-based approach was proposed by Atazadeh et al. [7] as a potential solution to overcome 3D cadastral challenges. There exists a rich amount of physical information inside the BIM models; however, ownership data elements are not recorded in BIM models, but it is possible to connect ownership data elements with BIM data by developing a specific application to link those two sets of data.

\subsection{Utility Cadastre}

Utility cadastre in the Republic of Croatia is defined by the Law on State Survey and Real Property Cadastre [8], and utility cadastre registers remain under the jurisdiction of local government (towns and municipalities). The State Geodetic Administration (SGA) of the Republic of Croatia suggested that the physical registration of utilities should be organized at a national level in the Republic of Croatia, and the law was changed in December 2016 to follow this direction. The newly adopted Croatian 
Utility Cadastre (when incorporated in the Croatian Land Administration System) should be able to streamline the provision of essential services such as water, sewerage, electricity, and communication networks. This normative decision saw the Law on State Survey and Real Property Cadastre align with Directive 2014/61/EU of the European Parliament and of the Council on 15 May 2014 on the impacts of reducing the costs of installing electronic high-speed communications networks. The Digital Agenda is a comprehensive plan of the European Commission to stimulate economic growth through the creation of a more competitive and modern digital Europe [9].

The mentioned and accepted changes of the current Law on State Survey and Real Property Cadastre passed all preparatory procedures. Based on the current status of the Utility Cadastre in the Republic of Croatia, the newly implemented Utility Cadastre should achieve the following goals [10]:

- To obtain information about the "occupancy of space" with regard to underground utilities and other infrastructure;

- To prevent infrastructure-related negative publicity, as well as prevent and reduce the cost of direct and indirect damage;

- To manage the infrastructure and implementation of conditions for keeping records of the utility infrastructure;

- To develop this in such a way that infrastructure data will merge with land cadastre data and be made available in the same projected coordinate reference system (Croatian Terrestrial Reference System 96 (HTRS96) for all interested parties).

Until now, most of the data was in an analogue form and therefore not fulfilling its potential. With the adopted changes to the Law, the 3D data of the utility cadastre will be maintained in digital form and as such, be made more suitable for 3D cadastre.

\subsection{Technical Aspects: Geodetic Projects, Digital Terrain, and Surface Models}

In Croatian official registers, there is insufficient data on the elevation of objects. However, data can be acquired through geodetic projects, and the available data on digital terrain and surface models can be utilized to establish a 3D cadastre.

The production of geodetic projects for construction and physical planning, as well as the production of utility cadastre reports (for public utility infrastructure), require the use of technical specifications to determine coordinates in the coordinate system of the Republic of Croatia. These specifications prescribe the correct ways to measure and store 3D coordinates in both analogue and digital forms for cadastral purposes (land, real property, and utility cadastre) as well as detailed topographic surveying, preparation of surveying maps, and all other georeferenced products.

Digital elevation models (DEM) provide basic quantitative information about the Earth's surface. Most data providers and professional users prefer the term DEM for both the digital terrain model (DTM) and the digital surface model (DSM). A DTM usually refers to the physical surface of the Earth (elevations of the bare ground surface) without objects such as vegetation or buildings, while a DSM describes the upper surface of the landscape, including the height of the vegetation, man-made structures and other surface features, and only gives elevations of the terrain in areas where there is little or no ground cover [11].

Data acquisition for the development of DTM and DSM are from 3D photogrammetric data acquisition from aerial images (stereopairs), as per the principles of the CROTIS (Croatian Topographic Information System).

Based on the principle of reusing public sector information, data on buildings and other man-made structures could be obtained from the subtraction of DTM and DSM as both models are available in the SGA. However, it can only currently be used for general or statistical purposes. For more specific purposes regarding 3D cadastre requiring higher demands of accuracy and precision, this method for obtaining quality $3 \mathrm{D}$ data is still not adequate. 


\section{Institutional Aspects of the 3D Cadastre}

Currently in Croatia there are no official records that can provide complete information on all buildings as spatial objects. Cadastre registers (which fall under the jurisdiction of the State Geodetic Administration) and land registers (under the jurisdiction of the Judicial Authority (Ministry of Justice)) are the only official and systematically maintained registers that contain data on real property [12] that also include buildings. The condition, integrity, and structure of the data collected on buildings maintained in these registers do not allow insight into the state and basic characteristics of certain buildings and the overall condition of buildings across the entire country. Therefore, one of the strategic objectives of the State Geodetic Administration is the establishment of a multipurpose cadastre of buildings to provide such information. The SGA has ordered an implementation study of the cadastre of buildings. This study has provided answers on how to establish institutional, legislative, and financial frameworks, and proposed a structure for the data model and technical standards for the information system of such a cadastre. Findings of the study pointed out that the State Geodetic Administration was the responsible institution for a cadastre of buildings. For detailed elaboration of a cadastre of buildings, the Law on State Survey and Real Property Cadastre should also be updated. Regarding the financial resources for the establishment of this new register, it should be provided from the State budget. Furthermore, this study also provided short-term and long-term strategic guidelines regarding system architecture, data model, the specific needs of stakeholders, the required legislation, the benefits delivered by such a system, and the financial resources needed for its establishment and maintenance. Our study also defined the implementation phases of a building cadastre based on the experiences of EU countries who had already introduced similar systems into their daily operations. The study, among other activities, further questioned the needs of the following future key users: the Ministry of Construction and Physical Planning, Tax Administration, Ministry of Justice, Ministry of the Interior Affairs, Croatian Chamber of Economy, National Protection and Rescue Directorate, Croatian Bureau of Statistics, Croatian Office for the State Property Management, and a representative sample of Croatian cities and municipalities. All of this was undertaken to involve the general public in the project and to consider the needs of the users which will bring-after the establishment of the unified multipurpose register of buildings-the added values of more regular spatial planning, property tax collection, the overall development of cities and municipalities, and the overall benefit to the state institutions and society as a whole [13]. Thus, the aim of the SGA was to develop a building cadastre based on the results of this study.

In Croatia, there are number of activities aimed at improving data, business processes, and the organization of land administration, and all of these fall under the National Real Property Registration and Cadastre Program known as Organized Land [14]. One of the project's key objectives is to realize and implement a Joint Information System (JIS) to combine both the land register and a cadastre. The JIS is a unique system which will replace the current different databases, cadastral data models, and associated applications in the cadastral offices of the State Geodetic Administration, as well as the land register databases and applications in the offices of the municipal courts. The SGA implemented the JIS in all cadastral offices in Croatia by November 2016. Today, the JIS provides support for the implementation of all regulated business processes and tasks, as well as transparent monitoring and data reporting from the cadastre and land registers. This system has special values in its administration and functionalities, and is hosted in a highly secure environment. The establishment of the JIS accelerates registration as it: (1) integrates the spatial and legal data of real property in both cadastral and land register systems; (2) raises the level of security in real property transactions; (3) provides better management of both systems; (4) streamlines business processes; (5) improves customer relations; and (6) increases the speed and quality of service. To provide the best speed and quality of services to key users and the general public, the State Geodetic Administration and Ministry of Justice developed (and continue to develop) a public One-Stop-Shop (OSS) web application that represents the link to the cadastral and land register data (or JIS). OSS allows all users to search and access an overview of the basic cadastral and land register data, but also contains a section for 
registered users who can then view the data, apply for public documents, view their case status, and receive issued documents into an electronic mailbox. Other additional cadastral data functionalities (to be implemented by the end of 2017) such as the electronic exchange of data between cadastral offices and licensed geodetic engineers, and the delivery of digital reports in cadastral offices, will standardize and speed up the review and confirmation of geodetic reports as well as accelerate the process of real property registration. Furthermore, this will also provide citizens with easy and quick access to public documents and data.

\section{Effects of Institutional Issues on the General State of Land Related Data}

Recently conducted research in Reference [4] included the analysis of land-related registers in the Republic of Croatia with the purpose of assessing the overall condition of land-related data. These registers primarily included data on land features such as cadastral parcels, buildings, and utilities (which can be found as the source of 3D data), as well as the interests (rights, restrictions, responsibilities) established over those features and spaces.

One of the aims of the abovementioned research in Reference [4] was to determine the level of redundancy between the registers closely related to the domain of land administration. For that purpose, the Land Administration Domain Model ISO 19152 (LADM) was used as it represents the basis of all land administration systems worldwide, including both the legal and the spatial components of land administration. In addition, a detailed analysis of the current legislation regulating the domain of registered data was conducted.

The analysis confirmed a significant amount of data redundancy, even at the level of individual public authorities responsible for governing multiple registers (Figure 3), which is a direct consequence of a non-existing linkage between the official registers. However, situations like this should not occur as the public authority responsible for more than one register has unrestricted access to all of the data, is fully familiar with the underlying data models, and should therefore be able to find simpler solutions for data sharing than when data is kept in different jurisdictions.

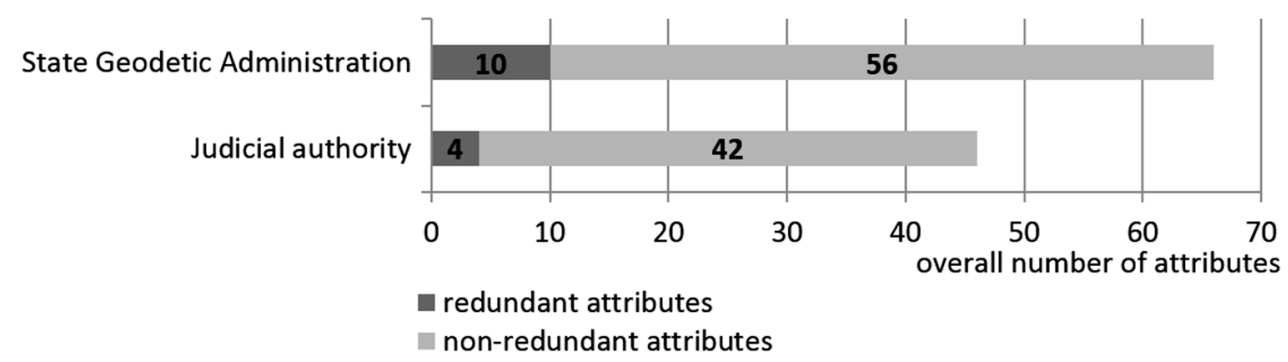

Figure 3. Redundancy at individual public authorities.

Additionally, situations like these should not exist in a mature information infrastructure (II) as part of the e-Government. A non-existing linkage is the primary reason for copying data from one register to another, thus producing redundancies. These data redundancies in the public authorities often lead to situations where data on land features in one register does not match the corresponding data in another register. Therefore, registers have often been viewed as unreliable, which undoubtedly lessens their actual value and creates unwanted consequences for the relevant public authority, as well as for citizens and companies as the end-users of that data. However, there are no excuses for keeping such redundant data. With the introduction of e-services as a form of modern Information and Communications Technology (ICT) [15], an environment has been created where there are no longer any technological barriers for data sharing, only those of administrative character. As a result, there is still no full systematic solution for linking registers at the data level in the Republic of Croatia. 


\section{Establishment of a 3D Multipurpose Land Administration System in Croatia}

Urbanization, which includes the development of high-rise apartments and the advent of complex building structures, has created unique challenges that cannot be met by 2D land and property information. These include interrelated titles and complex plans relating to [16]:

- cadastral parcels; and

- buildings, both internal (indoor plans) and external attributes (roof and façade).

Croatia does not have the complex buildings and structures found in Japan, China, or the Netherlands, but certain 3D situations exist which cannot be modelled in a 2D plane. One of the main problems in Croatia is that building data are scattered in several places including the topographical database, the registry of house numbers, the documentation acquired during building legalization, and so forth. Unfortunately, one direct consequence of such a state is the high level of data redundancy, which further causes additional errors in the data.

\subsection{Sources of 3D Data in Croatia}

Although data models for 3D data have existed for some time, the collection and generation of $3 \mathrm{D}$ data has not reached the level required to use 3D models across the wide variety of use cases as defined in Reference [17].

In Croatia, only the city of Zagreb has published 3D data online [18] for Zagreb and the neighbouring city of Zaprešić (Figure 4). Data can be viewed, and users can obtain basic information on buildings; furthermore, the Zagreb City Office for Strategic Planning and Development uses 3D data in its daily operations for strategic planning and urban development. However, these data cannot fulfil the needs of a 3D MLAS since the objects are modelled on the building level and building part. To attach various rights, restrictions, or responsibilities to building units, a further division of building parts in building units is necessary.

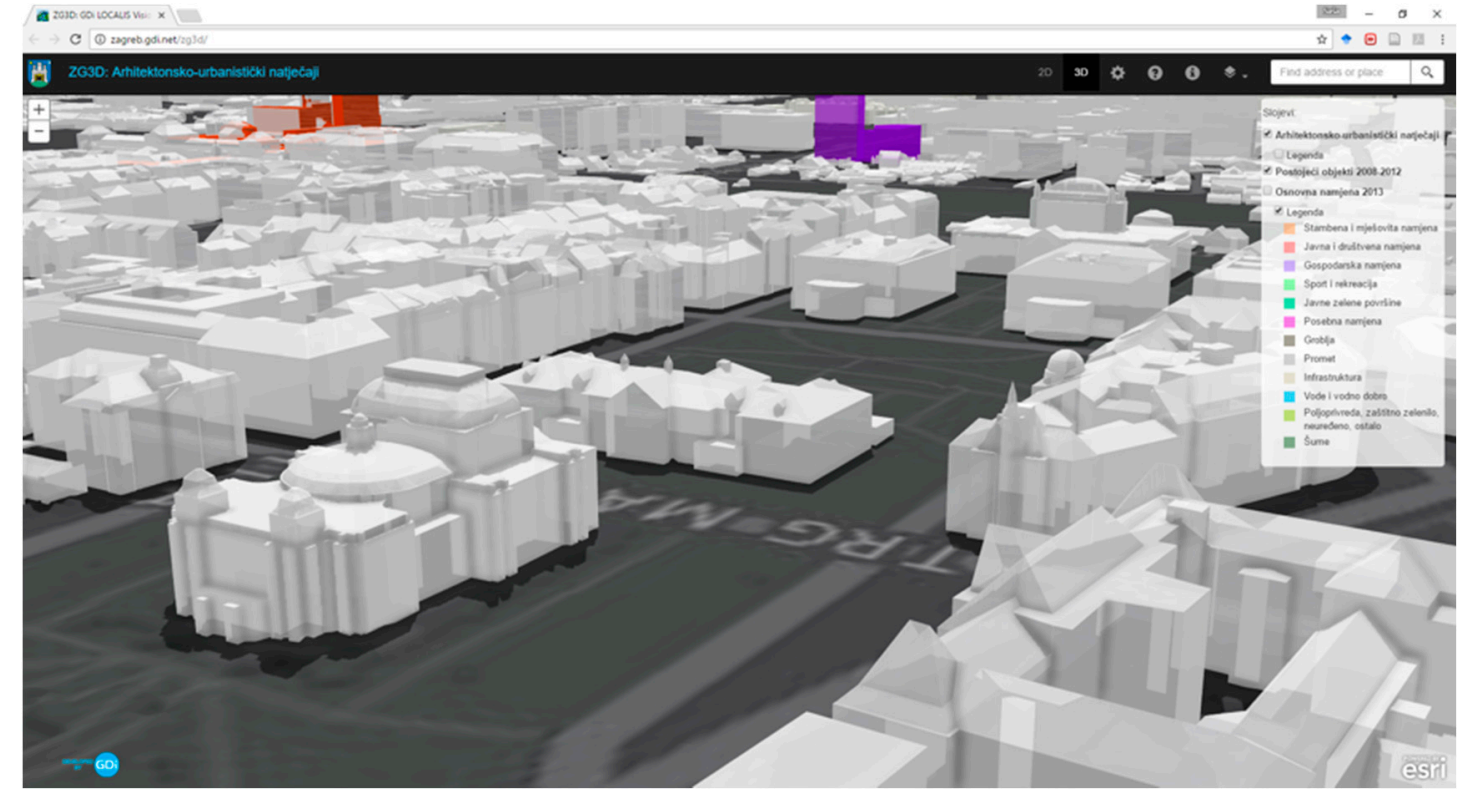

Figure 4. The Croatian National Theatre, Zagreb as displayed in the Zagreb 3D geoportal [18].

The implementation study of the multipurpose building cadastre in the Republic of Croatia is a State Geodetic Administration project, which is one step towards the establishment of a 3D MLAS [13]. One of the main outputs of the study was a conceptual model of a buildings cadastre that considered 
the available data and the needs of the stakeholders. The basis for the conceptual model was the INSPIRE directive, i.e., the data theme Buildings (Figure 5).

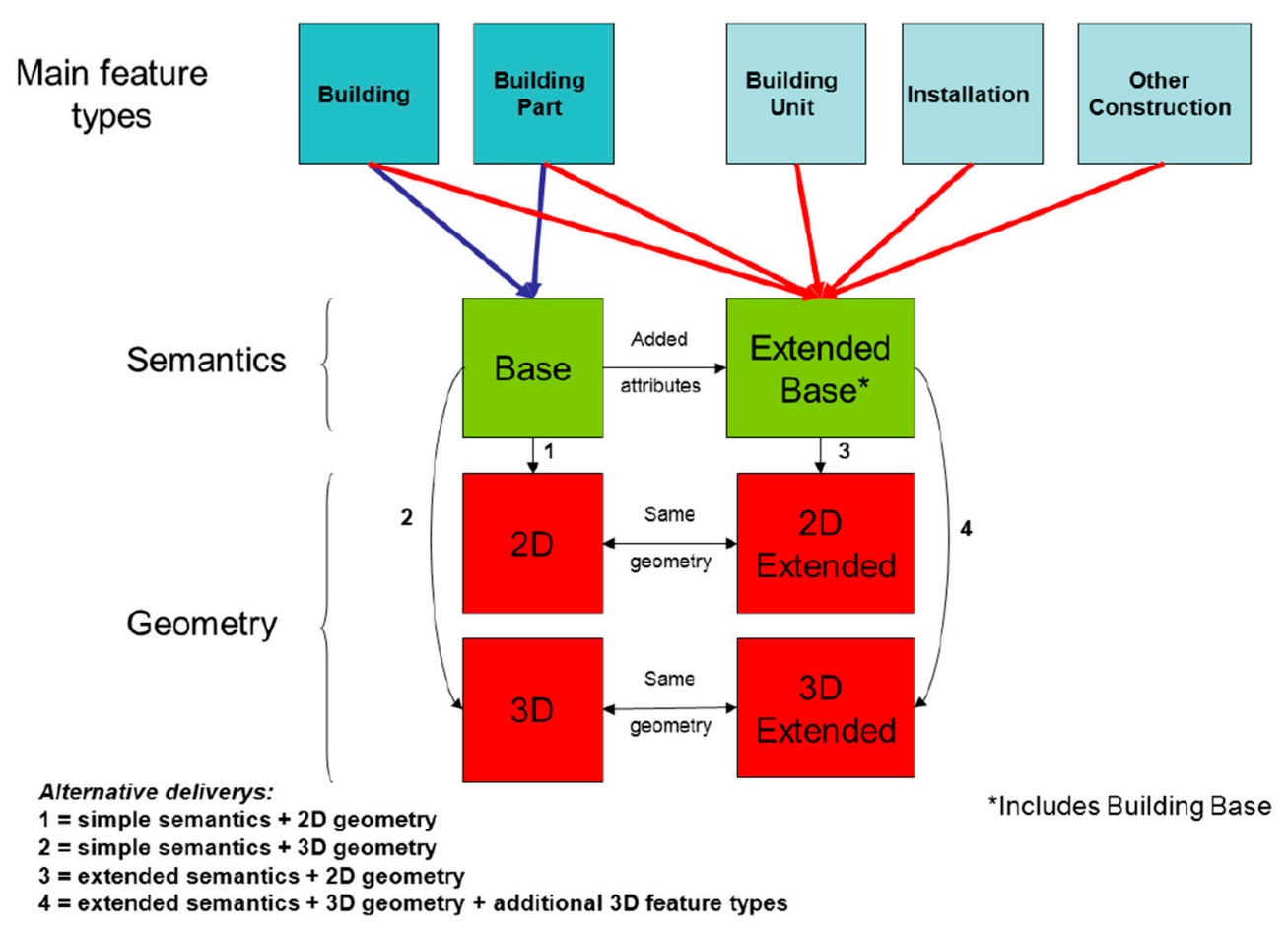

Figure 5. Content and structure of application schemas for the theme Buildings [19].

The INSPIRE Buildings theme uses CityGML for 3D model representation. CityGML defines five levels of detail (LoD): $\operatorname{LoD} 0, \operatorname{LoD} 1, \operatorname{LoD} 2, \operatorname{LoD} 3$, and $\operatorname{LoD} 4$. In addition, data specifications in the Buildings theme can define several profiles regarding the complexity and availability of data in buildings such as:

- 2D/3D Base;

- 2D/3D Extended.

A $2 \mathrm{D}$ geometry profile includes $2 \mathrm{D}$ or $2.5 \mathrm{D}$, i.e., a 2D footprint and height. A base profile only contains a basic set of building attributes while an extended profile has additional attributes including construction materials, installations, and relationships to other classes such as building units or cadastral parcels, addresses, and so on.

Since a large number of buildings in Croatia does not have any kind of technical documentation, information on these buildings need to be collected from existing data sources and represented in a 2D extended profile using LoD 0. For such buildings, a 3D model (LoD 1) could be created as explained in Reference [20]. Buildings and building parts that have technical documentation (for example, new buildings which have valid construction and usage permits) will be represented in 3D profile (LoD 2), while building units will be represented in $2.5 \mathrm{D}$ (footprint and height).

A great source of 3D data could be gained from the building legalization process, which has been in progress since 2012 [21]. More than 800,000 households have initiated the process of building legalization; as most households have more than one building, the number of buildings is much larger. At the time of writing (March 2017), more than 500,000 cases have been resolved. With future legal amendments on the treatment of illegally constructed buildings and other structures, the government of the Republic of Croatia has extended the deadline for submitting applications for legalization to the end of June 2018, and the number of cases for building legalization are likely to increase. For each building (based on size) in the process of legalization, a detailed project (for larger buildings) and 
footprint with height at the top and at the edges of the roof was provided (for smaller buildings). From that data, LoD 3 (for larger buildings) and LoD 1 or LoD 2 (for simpler buildings) could be created depending on building size.

One of the main problems with such data is its heterogeneity. Since there are no standards for building drawings, each company creates designs based on their in-house rules and standards. Some companies use Computer-Aided Design (CAD) applications, others use more advanced applications such as ArchiCAD. Given the lack of standardization, it is very difficult to implement an automated workflow to create 3D models.

\subsection{Technical Aspect of Establishing 3D MLAS}

The problems mentioned in the previous sections, such as data redundancy, unrelated data, data heterogenity, and errors in data, make the automatic generation of 3D models a challenging task. Initially, 3D models could be generated from the existing sources previously mentioned, or following the approach described by Biljecki et al. [20], or through the semi-automatic approach explained by Pouliot et al. [22]. Since existing 3D data are heterogenuous, a machine learning paradigm could be used to overcome slight differences in the data models across various sources.

Section 5 provides an overview of how certain 3D situations are represented on 2D cadastral maps with topographical signs. These situations could be combined with 3D data generated without elevation data as explained by Biljecki et al. [20], where it is simple to generate a 3D model from a cadastral map and the number of storeys. The height of the building was estimated by multipling the number of storeys with the average height of a single storey. Lines within buildings were used to enhance the 3D model generation algorithm.

Figure 6 shows the building footprint (blue line) represented on a cadastral map (a). Within the building polygon is a number which represents the building type. The red dashed line represents passage under the building. The red solid line represents the line which separates construction parts of the building, such as eaves or different building parts. Based on the type of line, it is possible to determine whether the building should be clipped from the top or from the bottom (b). The presumption is that the height of passage under the building is equal to the height of one storey. This presumption is valid for the majority of buildings in Croatia. It must be noted that this example is simplified and does not consider issues such as buildings that are not registered on the cadastral map, and the recognition of information on the number of building storeys from building permits and other documents. Although this idea has the potential to generate 3D models easily and quickly, it requires additional research to test the feasibility and accuracy of the data produced in this manner.

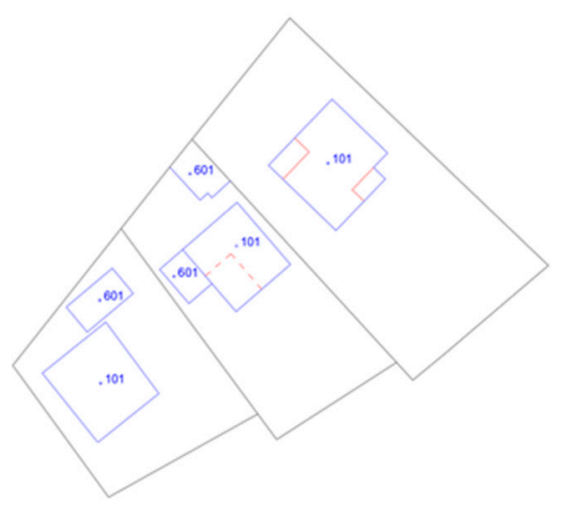

(a)

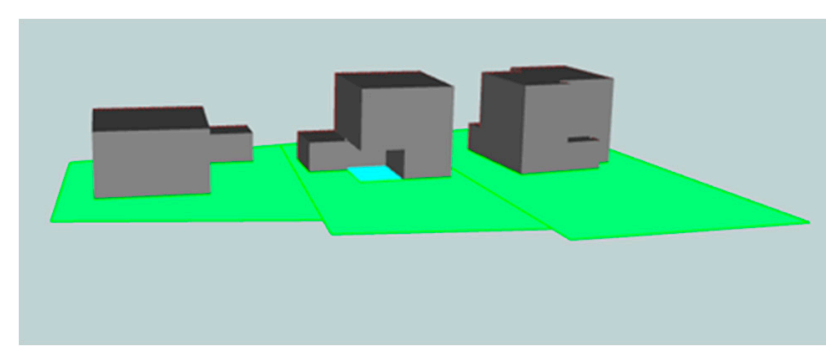

(b)

Figure 6. 3D model generated from (a) cadastral map, (b) 3D model.

Bennet et al. [23] recognized the criteria that future cadastres should satisfy to serve as a background for quality land administration, which include: 
- Improving the integration between the field data collection and execution of transactions on the data;

- Defining and formalizing the types of transactions on the data;

- Describing and formalizing the transaction processes for various types of transactions to outsource a large proportion of the updating process.

The previously listed criteria should be applied to a 3D Land Administration System since the private sector is generally more adaptable to user needs. To improve the modelling manner, storage, and exchange of field survey data, the international standard ISO 19156 can be used. Furthermore, the scientific literature contains publications on modelling land survey data and their integration with 2D cadastral data. Van Oosterom and Lemmen [24] explored the possibilities of modelling land survey data based on ISO standard 19156 (Observations and Measurements-O\&M). Vranić et al. [25] went a step beyond and developed a more refined model based on ISO 19156 for Global Navigation Satellite system (GNSS) observations that could be used for the efficient storage and retrieval of land survey data. In his Master's thesis, Soffers [26] proposed a solution for modelling relationships between survey data and resulting cadastral maps, i.e., spatial units based on the Land Administration Domain Model (LADM) sub package Surveying and Representation. Storing survey data in a digital form (that is, in readable form) to a computer that is related to spatial units enables easier searching and usage of the data. Mentioned studies have dealt with the integration of cadastral data with classical land survey data such as tachymetry or GNSS, but none of them address the modelling of 3D data from Light Detection and Ranging (LIDAR) or other sensors that produce 3D data. If 3D models are generated without elevation data (as explained in Biljecki et al. [20]) or from existing data gained from legalization (such as topographical databases, etc.), these sources and their relationship to spatial units should be modelled via the LADM LA_SpatialSource class.

A large proportion of 3D data can be acquired from existing data as explained previously, but the data are heterogenous and of different accuracy; however, this can be improved through the incremental updating of 3D data. If the process of updating 3D data is outsourced to the private sector, it is necessary to summarize the transaction types and their correctness conditions. Matijević et al. [27] performed a basic analysis of transactions in cadastre and planar partition as traditional European parcel-based cadastres use planar partition to manage their geometry. In a later work described in Reference [28], initial research on the correctness of cadastral parcels represented by simple polygons (as defined in international standards ISO 19107 and ISO 19125) was conducted where the authors defined the general criteria requiring satisfaction in order to correct the planar partition of the working area. Later, Vranić et al. [29] defined a complete list of transaction types on cadastral parcels and defined preconditions and postconditions for each transaction type. Although these papers concentrated on the correctness of 2D data, these can also be extended towards defining correctness criteria for 3D data. Initial research on the correctness of 3D data has already been conducted by Karki et al. [30] where they used ISO standard 19152 (Land Administration Domain Model: LADM) as a basis to define several encoding strategies for 3D data to ensure the achievable level. Furthermore, depending on the level of maturity of system validation, criteria can be defined.

\section{3D Topographical Data in Topographic Databases}

One consequence of the growing densification in urban land-use is an increase in situations regarding the vertical stratification of rights. As traditional 2D cadastral models are not able to fully handle spatial information on ownership rights in the third dimension, 3D cadastre has attracted researchers wanting to better register and spatially represent overlapping real-world situations [31].

Models of physical objects created from field observations may differ from legal object boundaries, and these differences between facts in the field and facts in the documentation can often become an obstacle in realizing the various rights related to land administration. Therefore, it is important that buildings are registered in the official registers (both in cadastre and land registers) in a way that 
accurately depicts the actual state of real property. Thus, we have physical 3D objects, legal objects with 3D space, and other categories such as economic objects that can be used in valuations.

\subsection{Buildings}

In the Croatian Land Administration System, there are special topographic signs for 2D maps showing 3D situations such as buildings overlapping other structures (such as tunnels, roads, or other parcels with building parts crossing the parcel boundaries either above or below ground level).

Additionally, there are also special signs that represent underground buildings on cadastral and topographic maps (Figure 7). Cadastre can register underground buildings only on cadastral maps and in the written part of cadastral documentation, but without area information, which can be documented in the land register. Many new underground buildings were built in Croatia during the last twenty ears, which is the reason behind the consideration of new regulations by the State Geodetic Administration of the Republic of Croatia that will enable the registration of underground buildings with area and other attributes into the cadastre.

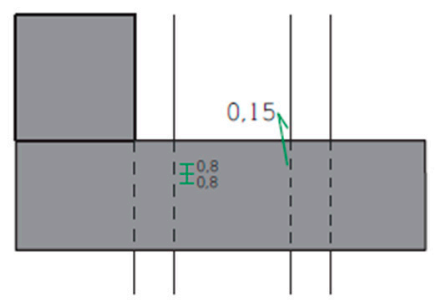

Passage under the building

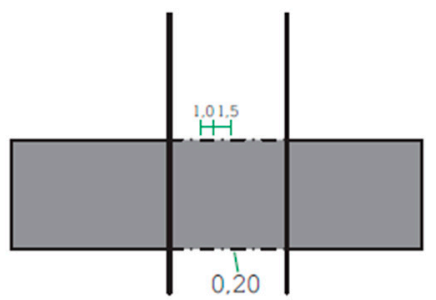

Building over the road

Figure 7. Example of topographic signs for buildings [32].

\subsection{Other 3D Situations from Real Life}

Other 3D real-life situations (such as pedestrian passageways) are also regulated by the geodetic and cadastral legislation. Good examples of potential 3D objects where representation can only be found in topographic signs on topographic maps are bridges, tunnels, pipelines, overpasses, etc. Furthermore, there are different topographic signs that serve a particular purpose and apply to different situations. For example, there are a few different types of bridges in the Croatian Land Administration System which are represented by different topographic signs (Figure 8).

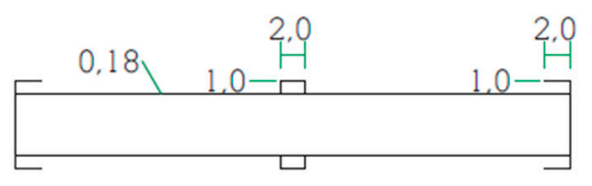

Stone and concrete bridge

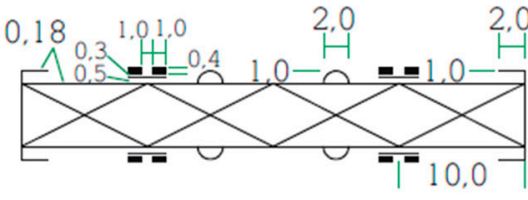

Iron bridge

Figure 8. Example of topographic signs for bridges [32].

In these cases, cadastral data are more complete and accurate, but lack important information on 3D objects. In contrast, topographic maps contain this type of information, but with less spatial accuracy. However, by combining cadastral data and topographic maps, it is possible to gain new values in terms of complete information on 3D space. 


\section{Link between Topographical Data and Cadastral Data}

The base register for large-scale topography forms an excellent context for 3D cadastral solutions as 3D cadastral parcels (3D legal spaces) are often related to (planned) physical objects such as buildings, tunnels, pipelines, and other constructions. For reference purposes, 3D legal objects and their 3D physical counterparts should be associated, which has two implications:

- That the 3D physical object descriptions (topographic objects) should exist, but are not obvious as most countries still use 2D representation for large-scale topographic base maps and;

- That the topographic objects should be usable and referenceable even when the data is maintained by other organizations.

LADM supports Spatial Data Infrastructure (SDI) implementations as the information infrastructure requires unique ID numbers for all objects, a full database history (versioning), and the blueprints of external classes such as topographic objects (buildings, tunnels, pipelines, etc.). LADM ensures the semantics of land administration data to other users within the SDI [33], and also provides conceptual descriptions for land administration, including 3D topology. Furthermore, it allows for land-related data to be organized in a standardized and interoperable way to support different types of spatial data. According to the requirements of LADM, topological information alone is not sufficient to describe a 3D spatial unit, and geometrical information must also be associated with each topological primitive either as direct or indirect geometries (via related topological primitives with geometries). For the 3D topology model in LADM as described in the Spatial profiles of Annex E7, there are no overlapping volumes (3D_SpatialUnit) [34].

For each real-life object in the Digital Topographic Database, a unified feature identifier can be assigned which can also be used to link with other cadastral data, for example, it can be implemented in an SGA Geoportal, which is the central place to access spatial data and is one of the basic elements of the National Spatial Data Infrastructure.

The SGA Geoportal consists of the following sets of data:

- 1:5000 digital orthophoto map, recorded and produced during 2011 for the whole country, and recorded and produced in 2014/2015 for some parts of country;

- Croatian Base Map 1:5000 (topographic);

- Topographic Maps 1:25,000, 1:100,000, 1:200,000;

- Digital cadastral maps (with the following contents: cadastral offices, cadastral municipality, cadastral parcels, buildings, house numbers);

- Central Registry of Spatial Units (counties, cities and municipalities, towns, local government);

- Generalized content 1:100,000 topographic map (roads, railways, ferry piers, lakes, waterways);

- Digital Terrain Model (DTM).

In the remainder of this section, two case studies are presented: (1) a road tunnel through a mountain; and (2) a pedestrian tunnel below a road.

\subsection{Croatian Topographic Information System (CROTIS)}

The Croatian Topographic Information System (CROTIS) version 1.0 data model was created in September 2000 [35] and served to define and standardize the data model and collection of topographic data, processing, accuracy, topological relations, and data exchange. CROTIS consists of the following five documents:

- Book I: Conceptual Data Model—Alphanumeric and Graphic Code System

- Book II: Topological Relations

- Book III: Exchange Data Structures and Exchange Graphic Models

- Book IV: Object Catalogue 
- $\quad$ Book V: Fundamental Principles

CROTIS was created as a model for the establishment of the Basic Topographic Database. In 2014, a new data model was developed under the name CROTIS 2.0. In the new data model, feature classes were grouped based on the analysis of identical attributes to ensure simple implementation into the object-relation database. During the development of the feature catalogue for the new CROTIS model, special attention was paid to defining the feature classes, attributes, and values. When defining new feature classes, consideration was made as to whether a feature class referred to, for instance, land cover (meadow, forest, rocks, etc.) or land usage (port, marina, beach, etc.) [36]. The CROTIS 2.0 data model consists of the packages shown in Table 1).

Table 1. List of packages and classes in the Croatian Topographic Information System (CROTIS 2.0).

\begin{tabular}{|c|c|}
\hline Package & Class \\
\hline Structures & $\begin{array}{c}\text { Building } \\
\text { Smaller structures } \\
\text { Larger structures } \\
\text { Built barriers }\end{array}$ \\
\hline Utility lines & $\begin{array}{c}\text { Utility line } \\
\text { Belonging elements of utility networks }\end{array}$ \\
\hline Traffic & $\begin{array}{c}\text { Traffic areas } \\
\text { Track } \\
\text { Surface elements of traffic } \\
\text { Line elements of traffic }\end{array}$ \\
\hline Cover and land use & $\begin{array}{l}\text { Agriculture land } \\
\text { Areas under the trees } \\
\text { Other natural areas } \\
\text { Public areas } \\
\text { Commercial areas } \\
\text { Land use }\end{array}$ \\
\hline Hydrography & $\begin{array}{c}\text { Wide water flow } \\
\text { Narrow watercourse } \\
\text { Coast line } \\
\text { Sea, standing water } \\
\text { Elements of the watercourse } \\
\text { Water barriers }\end{array}$ \\
\hline Relief & $\begin{array}{l}\text { Altitude } \\
\text { Depth } \\
\text { Isobath } \\
\text { Contours } \\
\text { Relief forms }\end{array}$ \\
\hline Geographical names & Geographical name \\
\hline
\end{tabular}

\subsection{Case Study 1: Tunnel}

Sveti Rok tunnel is a double-tube tunnel located on the Sveti Rok-Maslenica section of the Zagreb-Split-Dubrovnik Motorway. The length of the left tunnel tube is $5679 \mathrm{~m}$ and the length of the right is $5670 \mathrm{~m}$. The traffic runs through both tubes separately for each traffic direction. The northern tunnel portal is placed at $561 \mathrm{~m}$ above sea level and the southern portal at $510 \mathrm{~m}$. The tunnel passes through the Velebit Mountain in the corridor of the Mali Alan mountain saddle (Figure 9). 


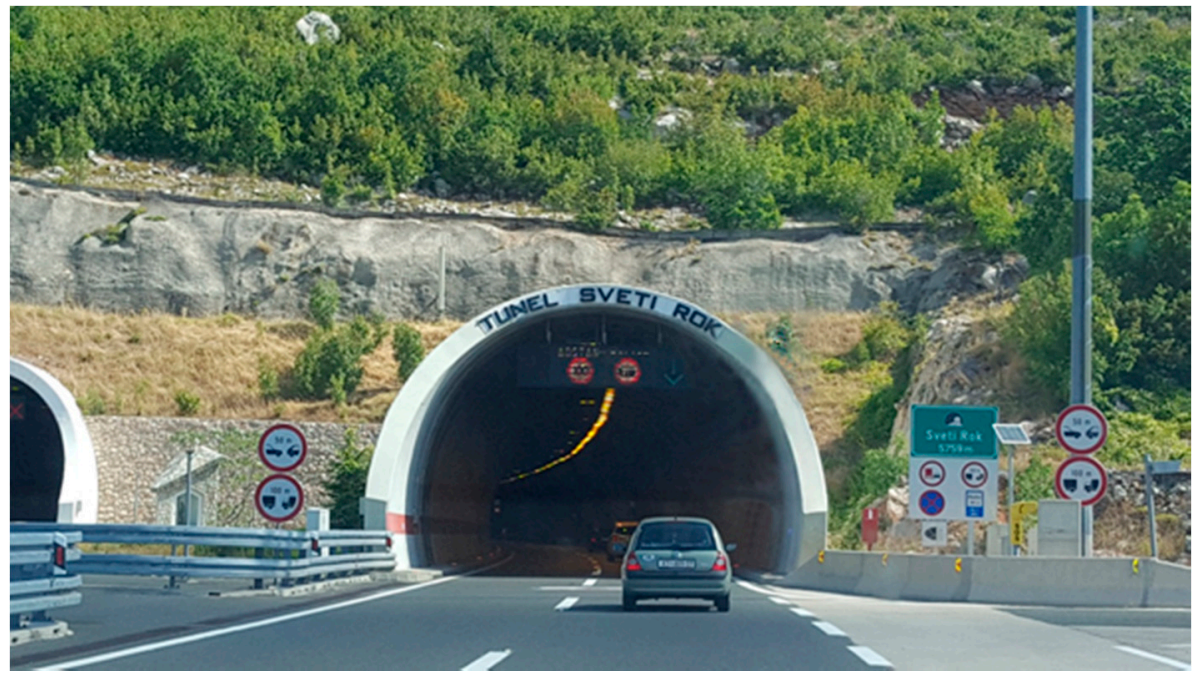

Figure 9. Sveti Rok road tunnel.

An example of tunnel representation in the Croatian Land Administration System is shown in Figure 10. The tunnel, which was built under many cadastral parcels, would, in a vertical sense, belong to those cadastral parcels. However, by functionality, it is permanently connected to the land where the entrance to the tunnel is located, and not to the cadastral parcels that extend above it. Therefore, according to legislation, the tunnel is permanently connected only to the land where the entrance is which makes it one property.

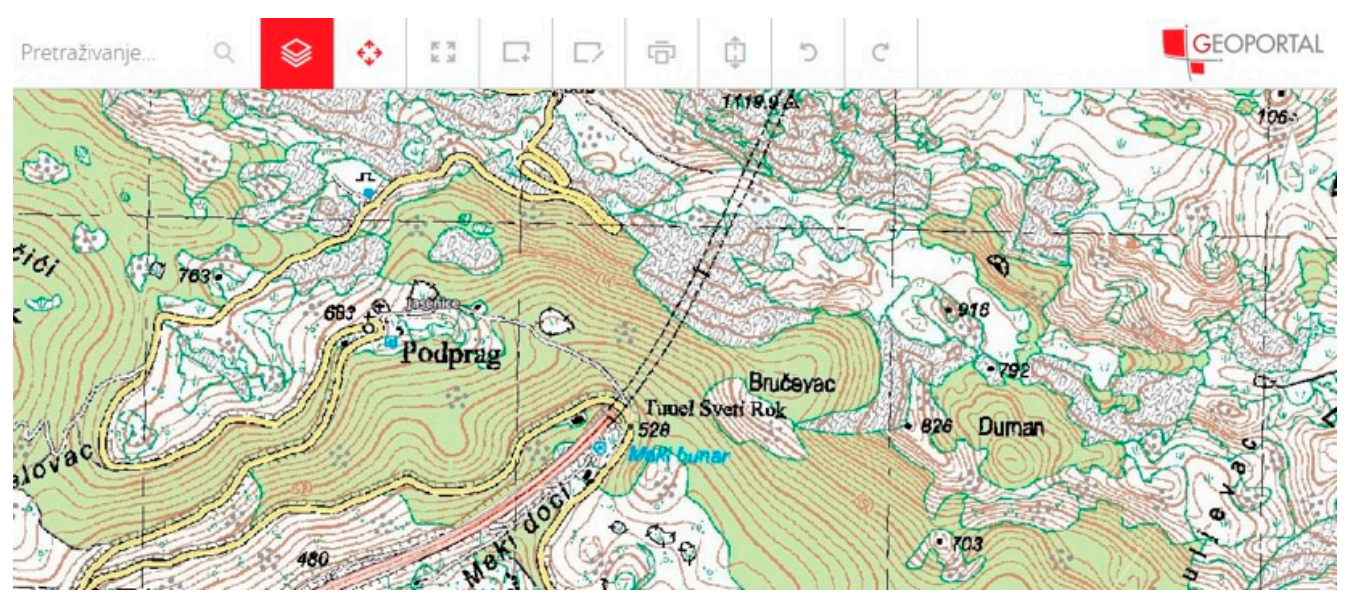

Figure 10. Tunnel as seen on a 1:25,000 topographic map [37].

\subsection{Case Study 2: Pedestrian Passage under the Street}

In Croatia, pedestrian passages under roads are mainly situated in large cities, and smaller towns do not usually have these 3D situations (Figure 11).

Further development of software and hardware technologies for spatial information has made it easy to combine geodetic and cartographic products in the modern digital environment. Today, all Croatian cadastral offices maintain digital cadastral maps overlapped with orthophoto images, and all other geodetic and cartographic products are available on the Croatian SGA Geoportal (Figure 12). At times, specific details are not shown on the cadastral map (like the underground passage from Figure 11), although there is a legal basis for its representation on the cadastral map. It is thought that 
this may be due to differences in time period during the map creation, as well as the selective and inconsistent application of the rules that may have caused these problems.

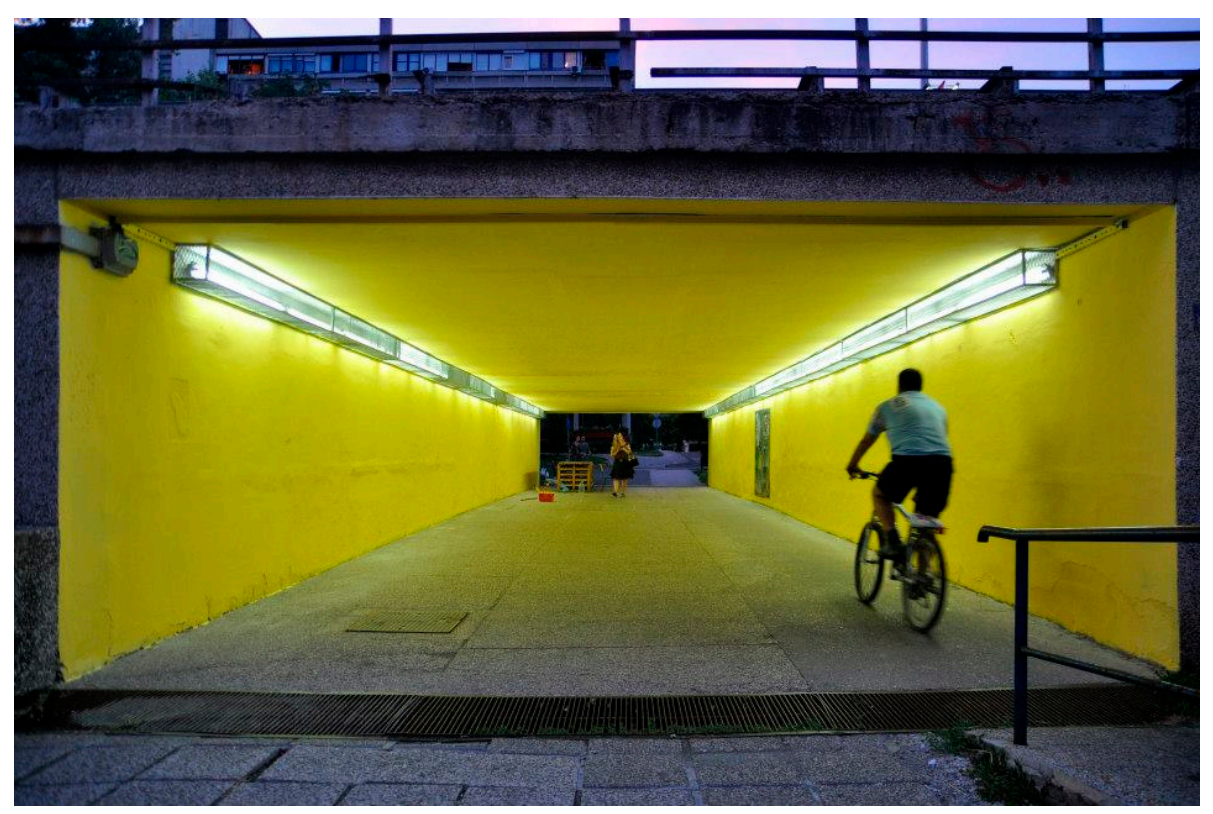

Figure 11. Pedestrian passage under the street in Zagreb, Savica [38].

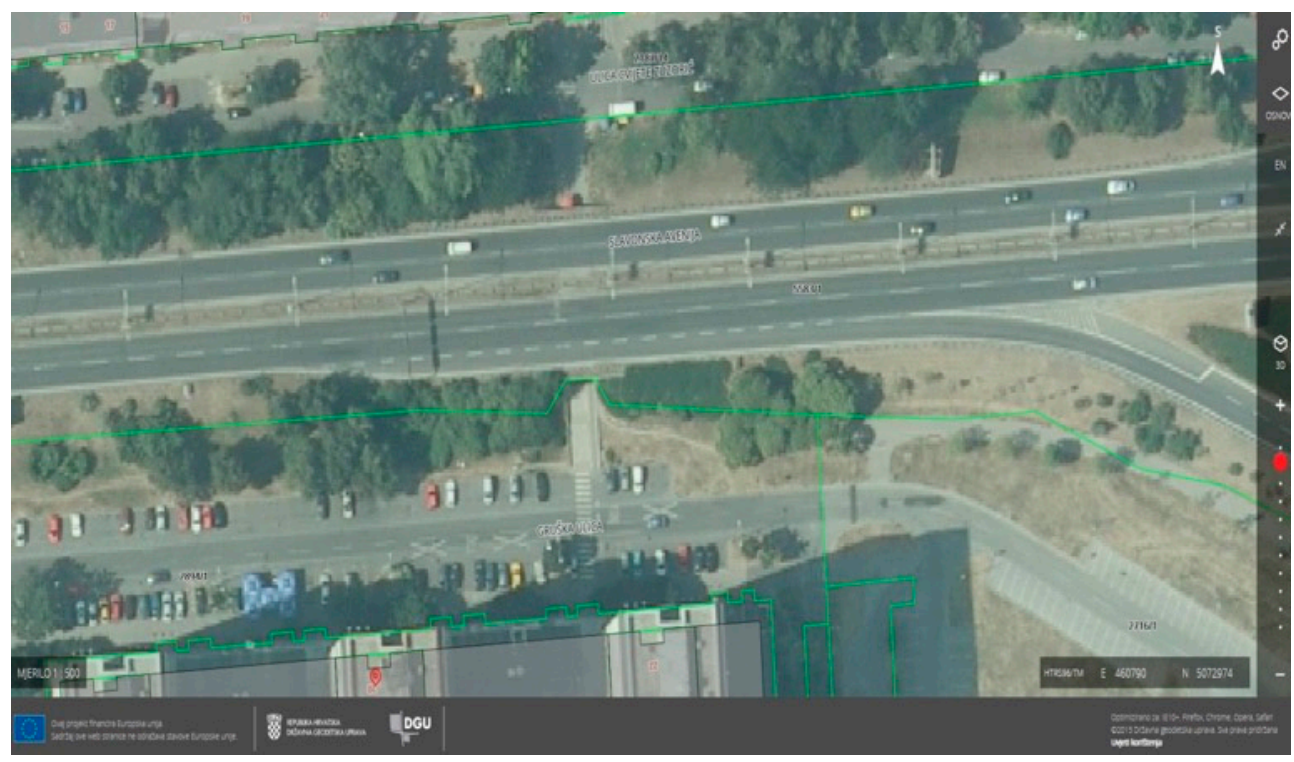

Figure 12. Pedestrian passage under the street in Zagreb, Savica, on the State Geodetic Administration Geoportal (digital ortophoto image overlapped with digital cadastral map) [37].

\section{Conclusions}

All branches of Croatian government-the legislative, judicial, and executive branches-are responsible for the land and associated land-related policies, each one of them within their own powers and competence. There are a great number of institutions responsible for land and different land-related policies, but each of them within their own scope of competence, and there is very little coordination between them. The scope of activities and competence of the public administration bodies are clearly regulated by law and formally, they should not be mutually overlapping. 
However, in the Republic of Croatia (and other countries where cadastre was established a long time ago) many registers and official databases on land and interests were created where certain overlaps between some segments are evident. These have most often been established independently and therefore contain much redundant data. However, their interaction can be used to gain new values and establish Multipurpose Land Administration Systems. As shown in this paper, there are multiple sources of 3D data in Croatia, including reports on a particular part of real property (deposited in the land register), digital terrain models and digital surface models, the Basic Topographic Database, the utility cadastre data, and the topographic content of cadastral and topographic maps (topographic signs). At a technical level, this problem can be solved by harmonizing the data model, for which the LADM can be used as a basis. However, legislative and institutional issues appear to be much more demanding tasks in practice.

It is not imperative that the 3D cadastre is established as soon as possible, instead, it is much more appropriate to develop it gradually and with good prioritization. It is indisputable that larger cities with more complex 3D situations in real life (such as a large number of public utility infrastructure, more underground structures, and many buildings with two or more floors) would have a greater use of the 3D cadastre compared to small towns, especially villages. A cost-benefit analysis of establishing a 3D cadastre in certain areas could be used to determine these priorities. The cost-benefit analysis undertaken in the implementation study of the building cadastre in the Republic of Croatia has shown that it would be feasible and cost effective to implement a building cadastre by the end of 2020, so that it could be used for the taxation of real properties based on their value, and for the 2021 census.

This study, among others, has provided an overview of the available 3D data in Croatia. As previously mentioned, the current data on buildings and other 3D objects are scattered, redundant, and loosely related. However, regulations defining the maintenance of cadastral maps and data collection workflow in a straightforward manner will allow for easier mass usage of the data. The simple test case presented in Section 4 shows how a 3D model could be generated by using a building footprint from a cadastral map and information on the number of floors. Further research will focus on testing the applicability and the usability of the currently available 3D data. Furthermore, various workflows for 3D model generation will also be created, which will include 3D data from multiple sources, and the generated 3D model will be tested in terms of completeness, accuracy, and correctness.

Acknowledgments: This work has been fully supported by the Croatian Science Foundation under project HRZZ-IP-11-2013-7714.

Author Contributions: Nikola Vučić, Miodrag Roić, Mario Mađer, and Saša Vranić contributed to organizing the research in part of the legal and institutional aspects of the Croatian cadastral system, as well as writing the paper. The materials for the paper were prepared by Nikola Vučić, Miodrag Roić, Mario Mađer, Saša Vranić and Peter van Oosterom. All authors have read and approved the final manuscript.

Conflicts of Interest: The authors declare no conflict of interest.

\section{References}

1. Roić, M.; Mastelić Ivić, S.; Matijević, H.; Cetl, V.; Tomić, H. Towards Standardized Concept of Multipurpose Land Administration. In Proceedings of the FIG Working Week, Christchurch, New Zealand, 2-6 May 2016.

2. Paulsson, J.; Paasch, J.M. 3D Property Research from a Legal Perspective. Comput. Environ. Urban Syst. 2013, 40, 7-13. [CrossRef]

3. Ploeger, H. Legal Framework 3D Cadastres. Position paper 1. In Proceedings of the 2nd International Workshop on 3D Cadastres, Delft, The Netherlands, 16-18 November 2011; pp. 16-18.

4. Mađer, M.; Matijević, H.; Roić, M. Analysis of possibilities for linking land registers and other official registers in the Republic of Croatia based on LADM. Land Use Policy 2015, 49, 606-616. [CrossRef]

5. Tušinec, I. Etažiranjem do vlasničkih ovlasti. Ekscentar 2005, 27, 23-29. (In Croatian)

6. Official Gazzette of the Republic of Croatia. Pravilnik o povezivanju zemljišne knjige i knjige položenih ugovora i upisu vlasništva posebnog dijela nekretnine (etažnog vlasništva). Available online: http:// narodne-novine.nn.hr/clanci/sluzbeni/2013_09_121_2596.html (accessed on 20 July 2017). 
7. Atazadeh, B.; Kalantari, M.; Rajabifard, A.; Champion, T.; Ho, S. Harnessing BIM for 3D digital management of stratified ownership rights in buildings. In Proceedings of the FIG Working Week, Christchurch, New Zealand, 2-6 May 2016.

8. Official Gazzette of the Republic of Croatia. Zakon o državnoj izmjeri i katastru nekretnina. Available online: https://www.zakon.hr/z/156/Zakon-o-dr\%C5\%BEavnoj-izmjeri-i-katastru-nekretnina (accessed on 20 July 2017).

9. E-Savjetovanja. Available online: https://esavjetovanja.gov.hr/ECon/MainScreen?entityId=3020 (accessed on 27 August 2016).

10. Vučić, N.; Roić, M.; Markovinović, D. Towards 3D and 4D Cadastre in Croatia. In Proceedings of the 4th International Workshop on 3D Cadastres, Dubai, UAE, 9-11 November 2014.

11. Varga, M.; Bašić, T. Quality Assessment and Comparison of Global Digital Elevation Models for Croatia. Kartografija i Geoinformacije: Zagreb, Croatia. J. Croat. Cartogr. Soc. 2013, 12, 20.

12. Roić, M. Upravljanje Zemljišnim Informacijama-Katastar; Faculty of Geodesy: Geodesy, Zagreb, 2012; Volume 199, p. 199.

13. State Geodetic Administration. Development of the Study on the Implementation of the Cadastre of Buildings in the Republic of Croatia. Available online: http:/ /www.dgu.hr/assets/uploads/OGLAS/ToR_ katastar\%20zgrada_HRV.pdf (accessed on 23 June 2017).

14. Organized Land. Available online: http://www.uredjenazemlja.hr/default.aspx?id=17 (accessed on 2 February 2017).

15. Van Oosterom, P.; Groothedde, A.; Lemmen, C.; Van der Molen, P.; Uitermark, H. Land Administration as a Cornerstone in the Global Spatial Information Infrastructure. Int. J. Spat. Data Infrastruct. Res. 2009, 4, 298-331.

16. Jazayeri, I. A geometric and semantic evaluation of 3D data sourcing methods for land and property information. Land Use Policy 2014, 36, 219-230. [CrossRef]

17. Biljecki, F.; Stoter, J.; Ledoux, H.; Zlatanova, S.; Çöltekin, A. Applications of 3D City Models: State of the Art Review. ISPRS Int. J. Geo-Inf. 2015, 4, 2842-2889. [CrossRef]

18. Zagreb Geoportal. Available online: http://zagreb.gdi.net/zg3d/ (accessed on 21 March 2017).

19. Data Specification on Buildings—Draft Technical Guidelines. Available online: http://inspire.ec.europa.eu/ documents/Data_Specifications/INSPIRE_DataSpecification_BU_v3.0rc3.pdf (accessed on 21 March 2017).

20. Biljecki, F.; Ledoux, H.; Stoter, J. Generating 3D city models without elevation data. Comput. Environ. Urban. Syst. 2017, 64, 1-18. [CrossRef]

21. Status of Building Legalization. Available online: https://legalizacija.mgipu.hr/izvjesce (accessed on 26 March 2017).

22. Pouliot, J.; Roy, T.; Fouquet-Asselin, G.; Desgroseilliers, J. 3D Cadastre in the province of Quebec: A First experiment for the construction of a volumetric representation. In Advances in 3D Geo-Information Sciences; Springer: Berlin/Heidelberg, Germany, 2011; pp. 149-162.

23. Bennet, R.; Rajabifard, A.; Kalantari, M.; Wallace, J.; Williamson, I. Cadastral features: Building a new vision for the nature and role cadastres. In Proceedings of the XXIV FIG International congress: Facing the challenges: Building the capacity, International Federation of Surveyors (FIG), Sydney, Australia, 11-16 April 2010.

24. Van Oosterom, P.; Lemmen, C.; Uitermark, H.; Boekelo, G.; Verkuijl, G. Land administration standardization with focus on surveying and spatial representations. In Proceedings of the Survey Summit, the ACSM Annual Conference, San Diego, CA, USA, 7-13 July 2011.

25. Vranić, S.; Mađer, M.; Matijević, H.; Bašić, T. Recording the CROPOS GNSS measurements in XML-A step towards digital geodetic technical report. In Proceedings of the 4th CROPOS Conference, Zagreb, Croatia, 22 May 2015; pp. 140-153.

26. Soffers, P. Designing an Integrated Future Data Model for Survey Data and Cadastral Mapping. Master's Thesis, Delft University of Technology, Delft, The Netherlands, 2017; p. 113.

27. Matijević, H.; Biljecki, Z.; Pavičić, S.; Roić, M. Transaction Processing on Planar Partition for Cadastral Application. In Proceedings of the FIG Working Week 2008 (FIG), Stockholm, Sweden, 14-19 June 2008.

28. Matijević, H.; Biljecki, Z.; Vranić, S. Correctness Preconditions For Changes on Geometry of Cadastral Parcels with Analysis of Implementation Options. In Proceedings of the Papers-1st Serbian Geodetic Congress (Republic Geodetic Authority), Beograd, Serbia, 1-3 December 2011; pp. 201-208. 
29. Vranić, S.; Matijević, H.; Roić, M. Modelling outsourceable transactions on polygon-based cadastral parcels. Int. J. Geogr. Inf. Sci. 2015, 29, 454-474. [CrossRef]

30. Karki, S.; Thompson, R.; McDougall, K. Data validation in 3D cadastre. In Developments in 3D Geo-Information Sciences; Springer: Berlin/Heidelberg, Germany, 2010; pp. 92-122.

31. Duarte-de-Almeida, J.P.; Liu, X.; Ellul, C.; Rodrigues-de-Carvalho, M.M. Towards a Property Registry 3D Model in Portugal: Preliminary Case Study Implementation Tests. In Innovations in 3D Geo-Information Sciences; Isikdag, U., Ed.; Springer: Cham, Switzerland, 2014; pp. 291-320.

32. Official Gazzette of the Republic of Croatia. Pravilnik o kartografskim znakovima. Available online: http:/ / narodne-novine.nn.hr/clanci/sluzbeni/2011_09_104_2118.html (accessed on 20 July 2017).

33. Jeong, D.; Jang, B.; Lee, J.; Hong, S.; Van Oosterom, P.; De Zeeuw, K.; Stoter, J.; Lemmen, C.; Zevenbergen, J. Initial Design of an LADM-based 3D Cadastre-Case Study from Korea. In Proceedings of the 3rd International Workshop on 3D Cadastres: Developments and Practices, Shenzhen, China, 25-26 October 2012.

34. Zulkifli, N.A.; Abdul Rahman, A.; van Oosterom, P. An overview of 3D topology for LADM-based objects. In Proceedings of the The International Archives of the Photogrammetry, Remote Sensing and Spatial Information Sciences, Kuala Lumpur, Malaysia, 28-30 October 2015; Volume XL-2/W4.

35. Biljecki, Z. Topografsko Informacijski Sustav RH-CROTIS; State Geodetic Administration: Zagreb, Croatia, 2000.

36. Landek, I.; Marjanović, M.; Šimat, I. Croatian Topographic Information System CROTIS 2.0. Data Model. Kartografija i Geoinformacije: Zagreb, Croatia. J. Croat. Cartogr. Soc. 2014, 14, 24.

37. State Geodetic Administration. Available online: http:/ / geoportal.dgu.hr (accessed on 23 February 2017).

38. Society of Architects of Zagreb City. Available online: http://www.d-a-z.hr (accessed on 27 August 2016).

(C) 2017 by the authors. Licensee MDPI, Basel, Switzerland. This article is an open access article distributed under the terms and conditions of the Creative Commons Attribution (CC BY) license (http:/ / creativecommons.org/licenses/by/4.0/). 